\title{
Hvem oppdaget insulinet?
}

\begin{abstract}
Sammendrag
Mange tror at insulinet ble oppdaget av Frederick Banting og Charles Best i Toronto i 1921-22. Men hvem som var opphavet til denne oppdagelsen har i alle år vært omfattet av stridigheter. Det oppsto tidlig konflikter i forskningsgruppen i Toronto, forsterket av tildelingen av nobelprisen i 1923 til John J.R. Macleod ved siden av Frederick Banting. Nobelpristildelingen førte også til sterke innsigelser fra rumeneren Nicolae Paulescu.
\end{abstract}

I 1982 publiserte historikeren Michael Bliss boken The discovery of insulin, et nitid forskningsarbeid som er blitt stående som den autoritative fremstilling av begivenhetene omkring oppdagelsen av insulinet. Bliss gir kreditt til alle de fire aktørene i Toronto: Banting, Best, Macleod og et for mange ukjent navn, James B. Collip. Det var Collip som først isolerte den pancreasekstrakten som kunne brukes i klinisk medisin.

Den første pasienten ble behandlet med insulin i januar 1922 i Toronto. I slående kontrast til stridighetene innad i Toronto-teamet var den første produksjon og internasjonale distribusjon av insulin preget av stor vilje til samarbeid og utveksling av erfaringer. Allerede i mai 1923 ble insulin tatt i bruk i Norge. Men introduksjonen av insulinbehandling ble ikke den endelige løsning av diabetesproblemet. Den venter vi på fremdeles, 90 år etter hendelsene i Toronto.

\section{Oddmund Søvik}

oddmund.sovik@pedi.uib.no

Institutt for klinisk medisin

Universitetet i Bergen

Oppdagelsen av insulinet regnes som en av de store begivenhetene i medisinens historie (1). For dem som for 90 år siden observerte virkningen av insulin på individer som var alvorlig syke med diabetes, fortonte dette seg som et genuint medisinsk mirakel. Omkring 1920 var diabetes mellitus for alle praktiske formål en ensartet sykdom, det vi i dag kaller type 1-diabetes. Forløpet var i typiske tilfeller kort, med død etter 6-12 måneder. Bare ved en ekstremt streng diett, som innebar sterk avmagring, kunne personene holdes i live. Det knyttet seg naturlig nok stor praktisk og vitenskapelig interesse til utforskningen av denne tilstanden, og når noen få injeksjoner av en pancreasekstrakt som ved et trylleslag kunne bringe dødssyke mennesker tilbake til livet, var dette intet mindre enn en medisinsk sensasjon.

En medisinsk oppdagelse kan komme uten noen bestemt forhistorie, nærmest som lyn fra klar himmel. Et eksempel på dette er Alexander Flemings (1881-1955) oppdagelse av penicillinet i 1928. Men som regel er det ikke slik. Vitenskapelige gjennombrudd er oftest resultat av mange forskeres anstrengelser gjennom en årrekke. Da kan man selvsagt diskutere berettigelsen av å gi heder og verdighet til bare én, eller noen få forskere.

Oppdagelsen av insulinet, som gjerne dateres til årene 1921-22, innebar mye dramatikk og fikk et etterspill som har pågått frem til i dag. Denne artikkelen er et streiftog gjennom denne historien, med to spørsmål for øyet: Hvem oppdaget insulinet - hvis det går an å snakke om én enkelt oppdagelse; og hvem fikk, og hvem burde ha fått nobelprisen for denne prestasjonen? Artikkelen er særlig basert på det nitide arbeid av historikeren Michael Bliss (2, 3). Frederick Bantings beskrivelse av hvordan insulin ble fremstilt og testet ut, finnes $i$ hans nobelforelesning (4).

\section{Hva man visste \\ før den første verdenskrig}

Selv om man omkring 1920 ikke kjente hormonet insulin, forelå det en stor, relevant kunnskapsmasse. Bukspyttkjertelens betydning for utviklingen av diabetes ble klarlagt på slutten av 1800-tallet. Franskmannen Eduard Hédon (1863-1933) demonstrerte at dyreeksperimentell fjerning av pancreas førte til utvikling av alvorlig diabetes. Hédon observerte også et fall i blodsukkernivået når blodsirkulasjonen hos en diabetisk hund ble knyttet til sirkulasjonen hos en frisk hund. Russeren Oscar Minkowski (1858-1931) og tyskeren Joseph von Mehring (1849-1907) viste at eksperimentell diabetes kunne bedres ved subkutan implantasjon av biter av pancreas. Tyskeren Paul Langerhans (1847-88) beskrev de celleformasjonene i pancreas som har fått hans navn. At disse cellene hadde betydning for utviklingen av diabetes, ble sannsynliggjort av russeren Leonid Szobolev (1876-1919), som viste at ligering av utførselsgangen fra pancreas, med påfølgende atrofi av de eksokrine cellene, ikke påvirket glukosestoffskiftet hos forsøksdyrene. Sett under ett tydet alle disse observasjonene på at det i de langerhanske øyer ble dannet et stoff som hindret utviklingen av diabetes. Dette hypotetiske stoffet ble betegnet som insuline av den britiske endokrinologen Edward SharpeySchäfer (1850-1931).

\section{Tidlige studier}

\section{av pancreasekstrakter}

Det var selvfølgelig nærliggende å lete etter insulin i ekstrakter av pancreas, og slike forsøk var påbegynt flere år før gruppen i Toronto startet opp. To arbeider skal nevnes. Rumeneren Nicolae Paulescu (1869-1931) startet eksperimenter i 1916, men måtte stoppe pga. krigen. I 1919 tok han opp igjen forsøkene hvor han testet ut saltvannsekstrakter av pancreas ved intravenøs injeksjon på diabetiske hunder. Han observerte reproduserbare blodsukkerfall og reduksjon av sukkerutskillelsen i urinen. Observasjonene ble publisert i det velrenommerte Comptes rendus des séances de la Société de Biologie (5). Paulescu brukte navnet pancratine om det aktive stoff. Franskspråklig publisering skulle i denne forbindelse vise seg å være en ulempe. En annen forsker som var tidlig ute, var Israel Kleiner (1885-1966) ved Rockefeller-instituttet i New York. Som Paulescu laget han saltvannsekstrakter av pancreasvev og injiserte disse intravenøst på pankreatektomerte hunder. Han observerte reproduserbare blodsukkerfall på omkring $50 \%$. Resultatene ble publisert i Journal of Biolo- 
gical Chemistry i 1919 (6). Men Kleiner forlot Rockefeller i 1919, og det kom ikke flere arbeider fra hans hånd om dette emnet.

\section{Toronto-gruppen}

De dramatiske hendingene i 1921-22 er beskrevet i stor detalj av Michael Bliss $\mathrm{i}$ hans bok The discovery of insulin $(2,3)$. Det faktum at de fire aktørene, Frederick Banting (1891-1941), Charles Best (18991978), James B. Collip (1892-1965) og John J.R. Macleod (1876-1935) var svært forskjellige både med hensyn til utdanning og temperament, skulle komme til å forårsake mye turbulens.

Det opprinnelige initiativet kom fra Banting. Han hadde kirurgisk bakgrunn, var uten forskningsmessig erfaring, men var grepet av tanken om å finne stoffet som kunne helbrede diabetes. Hans berømte idé, som han presenterte for Macleod, professor i fysiologi ved universitetet i Toronto, var å ligere utførselsgangen fra pancreas på hunder, med påfølgende atrofi av kjertelens eksokrine del. Dette ble antatt å lette isoleringen av en aktiv substans fra de langerhanske øyer. Det skulle vise seg at dette bare var en kompliserende prosedyre, og teknikken ble snart forlatt.

Banting fikk som assistent medisinstudenten Charles Best, og de startet sine eksperimenter sommeren 1921. De klarte, liksom sine forgjengere, å lage pancreasekstrakter som hadde blodsukkersenkende effekt ved intravenøs injeksjon på diabetiske hunder, men resultatene var lite reproduserbare. Etter råd fra Macleod gikk de høsten 1921 over til å ekstrahere umodifiserte pancreaskjertler med alkohol, noe som ga større utbytte av ekstrakt til utprøving.

Det oppsto tidlig samarbeidsproblemer i gruppen. Banting, som i starten opplevde lite entusiasme for prosjektet, reagerte svært negativt da Macleod senere overtok styringen. Mot slutten av 1921 kom Collip, som var en erfaren biokjemiker, med i arbeidet. Han benyttet pancreas fra okser og ekstraherte med fortynnet etanol. Ved gradvis økning av alkoholkonsentrasjonen ble han kvitt mye forurensende protein ved utfelling, inntil insulinet selv ble utfelt ved en alkoholkonsentrasjon på over $90 \%$. Collip testet ut sine ekstrakter på kaniner og i januar 1922 hadde han preparater klare til bruk i kliniske forsøk.

Den 14 år gamle Leonard Thompson (1908-35) fikk 23. januar 1922 en subkutan injeksjon med $5 \mathrm{ml}$ ekstrakt. Neste dag fikk han to injeksjoner, hver på $10 \mathrm{ml}$. Guttens blodsukkerkonsentrasjon sank fra $520 \mathrm{mg}$ til $120 \mathrm{mg}$ per $100 \mathrm{ml}$ blod. Ketonurien svant. 50-årsminnet for dette ble markert bl.a. i Tidsskriftet i 1972 (7). Det hører med til historien at den samme pasienten kort tid forut var blitt behandlet med en ekstrakt fremstilt av Banting og Best. Denne injeksjonen hadde vært nærmest virkningsløs, bortsett fra at den etterlot en steril abscess på stikkstedet. En annen pasient, Theodore Ryder (1916-93), fikk diabetes fire år gammel og var «et levende skjelett» da han fikk sin første injeksjon med Collips ekstrakt. Ryder unnslapp diabetiske senkomplikasjoner og døde 76 år gammel av hjertesvikt.

Collips suksess var vanskelig å svelge for Banting og Best som hadde lite hell i kliniske forsøk med egne ekstrakter. Det oppsto gjensidig mistillit, hvor Collip var engstelig for at Banting og Best skulle overta hans ekstraksjonsmetode som sin egen, mens Banting på sin side fryktet at Collip skulle ta med seg metodikken og forlate gruppen. Under en konfrontasjon gikk den emosjonelt ustabile Banting til fysisk angrep på Collip og la ham i gulvet. Men som Best senere mintes, «Collip was not seriously hurt». «I can remember restraining Banting with all the force of my command» (2). Gemyttene roet seg imidlertid, og de vellykkede behandlingsresultatene ble publisert i det kanadiske legetidsskriftet (8), og fikk stor oppmerksomhet på et møte i The Association of American Physicians, Washington D.C., 3. mai 1922.

I ettertid la Banting og Collip stridighetene bak seg, og privat var Banting raus nok til å erklære at han og Best «wouldn’t have achieved a damned thing without Collip» (2). Men Bantings hat mot Macleod, forsterket av nobelpristildelingen, svant aldri.

Collip forlot Toronto og Macleod reiste hjem til Skottland. Banting og Best ble feiret som Torontos helter, og hele den moderne verden meldte sin interesse for det nye vidunderstoffet.

\section{Dansk insulin og internasjonalt samarbeid}

I slående kontrast til stridighetene innad i Toronto-teamet var den første produksjon og internasjonale distribusjon av insulin

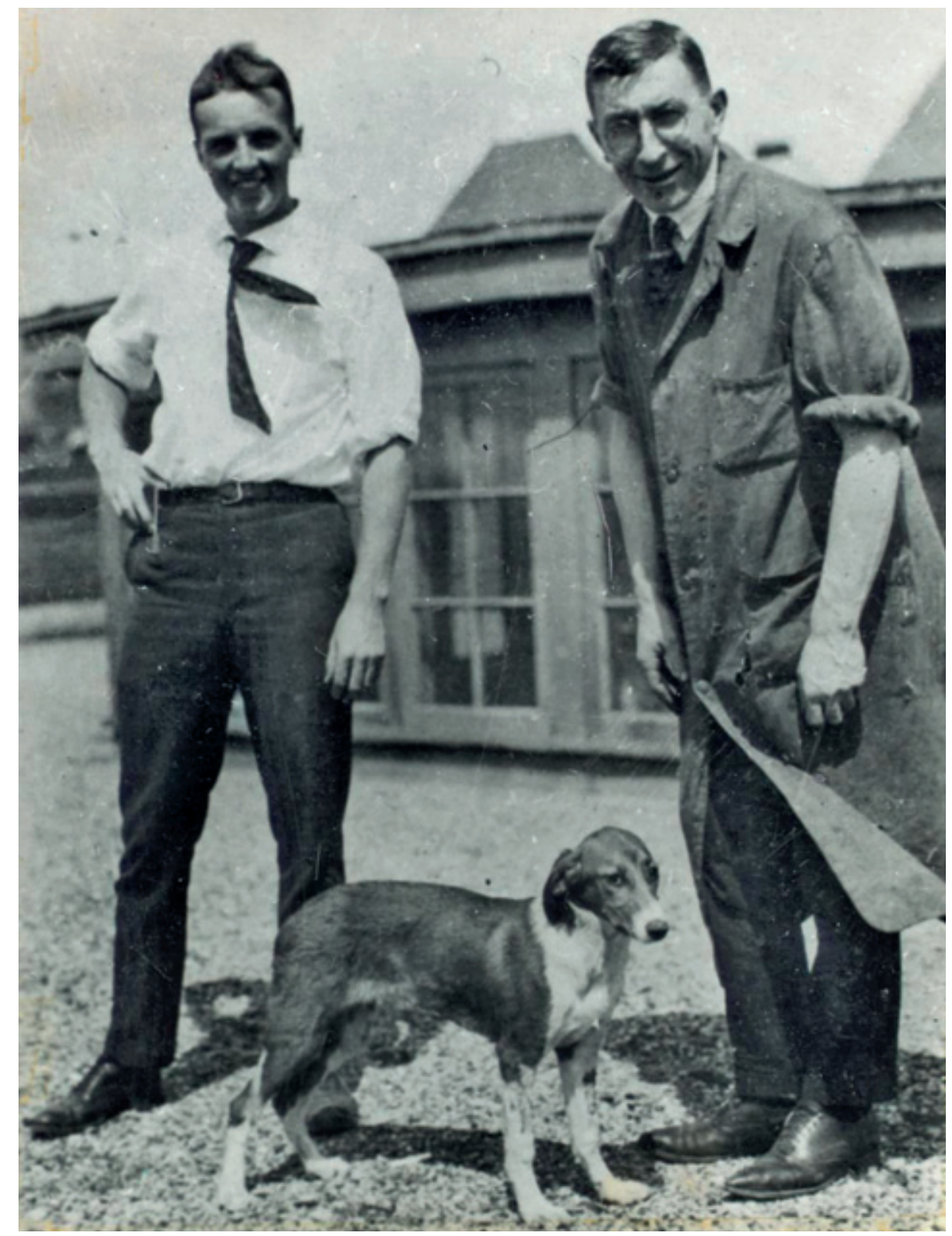

Charles Best (1899-1978) til venstre og Frederick Banting (1891-1941) i Toronto 1921. Gjengitt med tillatelse (3) 


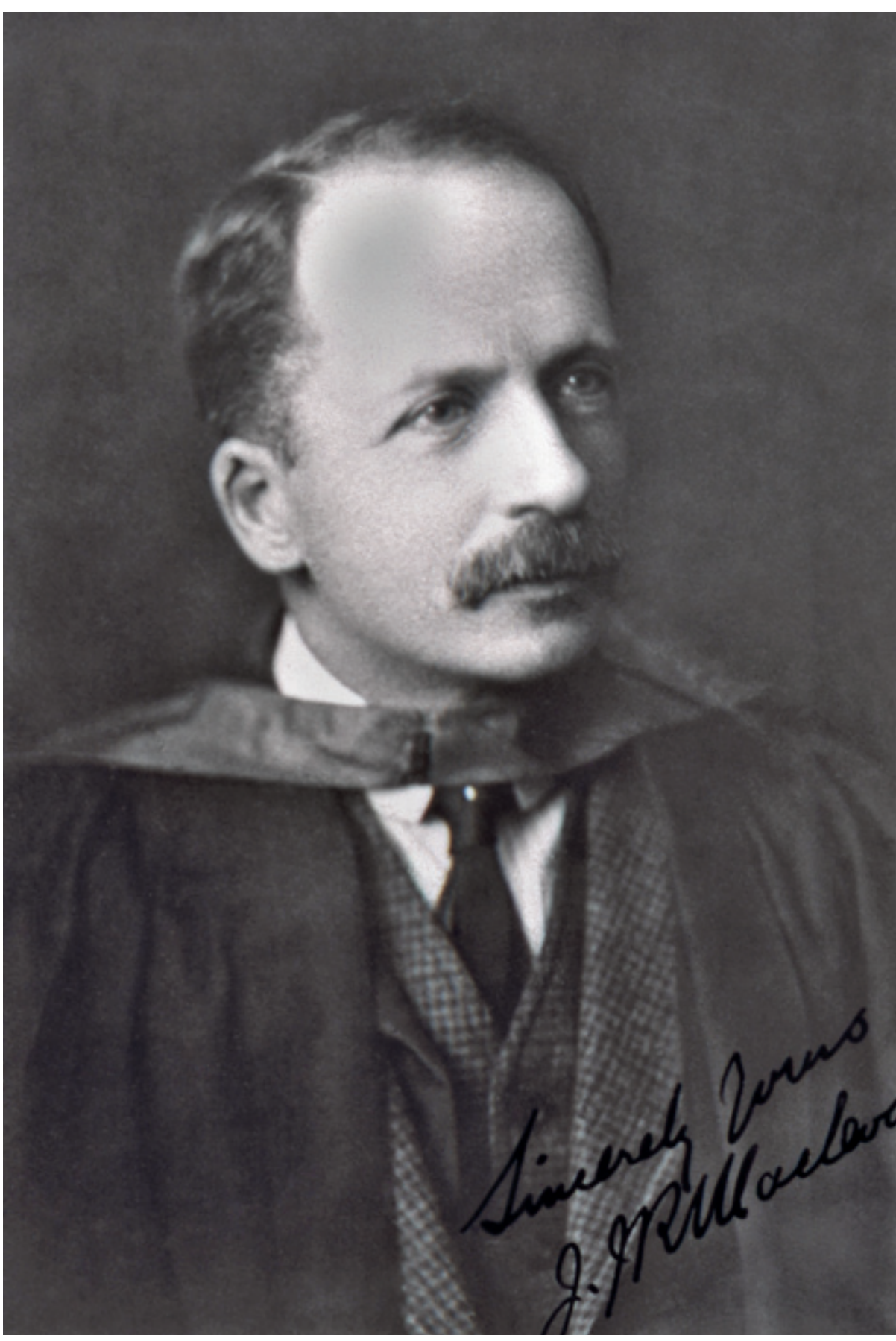

John J.R. Macleod (1876-1935), professor i fysiologi ved universitetet i Toronto (1918-28). Foto Istockphoto

preget av en enestående vilje til samarbeid og utveksling av erfaringer. Man var opptatt av at det nye vidunderstoffet raskest mulig skulle komme pasientene til gode. Tanken om profitt kom i bakgrunnen. Den patenten som ble tatt ut i navnene til Banting, Best og Collip, ble administrert av en såkalt insulinkomité ved Toronto-universitetet. Man hadde lite forsinkende byråkrati, og etter dagens standard skremmende få kontrollrutiner. Resultatet ble at insulin etter forbausende kort tid var tilgjengelig for store pasientgrupper i Nord-Amerika og Vest-Europa.

Situasjonen 1922-23 illustreres av en bemerkelsesverdig suksesshistorie, nemlig polis, USA, og det britiske Medical Research Council oppnådd tilsvarende avtaler. Insulinproduksjonen i Toronto ble besørget av Connaught-laboratoriet.

Etter hjemkomsten til Danmark valgte Krogh den unge legen Hans Christian Hagedorn (1888-1971) til å lede fremstillingen av insulin. Hagedorn fikk ansvar for ekstraksjonen av bukspyttkjertler, i hovedsak fra storfe, mens ekstraktenes biologiske effekt ble målt i Kroghs laboratorium. Allerede 13. mars 1923 ble insulin injisert på den første danske pasienten.

Blodsukkernivået falt, men pasienten døde. Senere gikk det bedre, og 9. juni 1923 kunne Hagedorn rapportere om vellykkede resultater i Ugeskrift for Laeger (9). I mai 1923 ble Nordisk Insulinlaboratorium grunnlagt, og innen kort tid annonserte Krogh at insulin kunne leveres til alle indremedisinske avdelinger i Skandinavia. Ifølge Jak Jervell (f. 1932) skal hans far, Anton Jervell (1901-87), som ung lege ha vært til stede da den første norske pasienten fikk insulin, i mai 1923 (10). Frem til januar 1924, etter et halvt års bruk, hadde man behandlet 18 pasienter med insulin, «det vidunderlige stof» (11).

\section{Diskusjon}

Oppdagelsen av insulinet er blitt stående som en av de store hendingene i medisinens historie, med en betydning som knapt kan overvurderes. Fordi man her står overfor en stor og betydningsfull medisinsk hending, er det særlig viktig at den medisinskhistoriske beretning blir korrekt. Men å følge begivenhetene som utspant seg i Toronto er i seg selv fascinerende. Og det er en viktig historie som viser oss forskningens forskjellige menneskelige ansikter, uforutsigbare eller forventede.

Det er makthaverne som skriver historien, heter det. I medisinens og forskningens verden vil det være et spørsmål om hvem som når ut til den medisinske verden og allmennheten med sitt budskap. Forskerverdenen gjenspeiler storsamfunnet, med kamp om ressurser og posisjoner, og streben etter prestisje og utmerkelse. Raushet veksler med smålighet, åpenhet står mot mistenksomhet, ærlighet mot svindel. Tvilsomme menneskelige egenskaper åpenbares når mye står på spill. Ønsket om å sikre sitt ettermæle kan bli dominerende, slik at historien forsøkes skrevet om eller pyntet på.

Forskerens drøm og håp er å finne noe nytt og epokegjørende, men bare de færreste opplever dette. Fleming oppdaget penicillinet pga. et våkent øye og «a prepared mind». Det var annerledes med insulinet. Her var det egentlig ikke snakk om en «oppdagelse», fordi man hadde en mengde holdepunkter for at den endokrine pancreas huset et blodsukkersenkende prinsipp. Oppgaven ble derfor å isolere og rense, heller enn å «oppdage». Insulin kom i «tidens 
fylde», som konsekvens av en langvarig forskningsprosess med bidrag fra mange aktører. «Oppdagerne» kunne høste frukten av andres langvarige arbeid. En viktig forutsetning for gjennombruddet i 1921-22 var, foruten det som allerede er nevnt, tilgjengeligheten av metoder til måling av glukosekonsentrasjon i små mengder blod.

Med sin nøyaktige dokumentasjon av hendingene i Toronto 1921-22, så å si fra dag til dag, har Michael Bliss effektivt fjernet myten om Banting og Best som de store oppdagerne av insulinet. Likevel er hans konklusjon forsiktig, ved å gi kreditt til alle de fire aktørene: Banting, Best, Macleod og Collip, i nevnte rekkefølge. Torsten Deckert er derimot ikke i tvil (9): «Opdagelsen av insulin var ikke Banting og Bests værk. De havde ikke én original idé, de bidrog med initiativ og energi, men opdagelsen av insulin var først og fremmest Macloed og Collips værk. Det var takket være deres viden, organisation og kreativitet at 3 dekaders bestræbelser for at udvinde det blodsukkersænkende princip fra pankreas førte til fremstilling af et præparat, der var egnet til klinisk brug. Det som Banting og Best var nået til var ikke egnet til patientbehandling» (9). Deckert gir også full kreditt til de arbeidene som var publisert før Toronto-gruppen kom i gang, og konkluderer med at det var Kleiner og Paulescu som uavhengig av hverandre oppdaget insulinet. Denne oppfatningen kan forsvares ut fra en rent biologisk synsvinkel, for det synes klart at det var virkningen av insulin både Kleiner og Paulescu observerte i sine dyreforsøk. Ser vi derimot spørsmålet fra et medisinsk synspunkt, er det åpenbart at virkningen av insulin i kliniske forsøk først ble demonstrert i Toronto. Men det var biokjemikeren Collip som renset ekstrakter som kunne brukes i kliniske forsøk. Dette er Collips originale og betydelige bidrag til denne historien. Det er tvilsomt om Banting og Best, med deres høyst mangelfulle biokjemiske bakgrunn, noen gang hadde vært $i$ stand til å lage ekstrakter brukbare i klinisk sammenheng. Det må likevel understrekes at uten Bantings initiativ, motivasjon og vilje til å gjøre en oppdagelse, hadde dette forskningsgjennombruddet ikke kommet i Toronto.

Nobelprisen i fysiologi eller medisin for 1923 gikk til Banting og Mcleod, som foreslått av August Krogh. Men i flere kilder, bl.a. på nettsidene til den internasjonale diabetesføderasjon (12) og pasientorganisasjoner (13) er Banting og Best blitt stående som oppdagerne av insulinet. Få eller ingen har hørt om Collip. Like fullt var Collip forskningsmessig sett den mest innovative personen i Toronto-teamet. At så få kjenner navnet Macleod og hans bidrag, kan ha å gjøre med striden mellom ham og Banting, hvor de fleste tok Bantings parti. Og Banting la aldri skjul på sitt syn, verken privat eller offentlig, nemlig at Macleod hadde vært lunken til hele prosjektet inntil han øynet en nobelpris. Denne oppfatningen har nok heftet ved Macleod i ettertid (14).

Hvem var så denne Frederick Banting som på kort tid avanserte fra det ukjente til ære og berømmelse? Historikeren Michael Bliss gir oss bildet av en interessant og sammensatt personlighet. Av natur var han sårbar, mistenksom og oppfarende. Samtidig hadde han et godt smil og glimt i øyet. Han hadde ikke vært spesielt skoleflink og var usikker på hva han skulle slå inn på etter legeutdanningen. Under den første verdenskrig var han stasjonert i England og fikk en del erfaring som skadekirurg. 28 år gammel var hans situasjon lite oppmuntrende. Han hadde bak seg en mislykket legepraksis, og kjæresten hadde nettopp brutt forholdet. Han reiste til Toronto for å forske på diabetes, men hadde ingen teoretisk eller praktisk bakgrunn og forble vitenskapelig uskolert. Hans arbeid var unøyaktig og lesningen var overfladisk. Men han må ha vært uvanlig motivert for forskning, med en voldsom «drive». Etter oppnådd berømmelse vistes hans sosiale sider. Han fremsto som en eventyrskikkelse og sjarmerte både leg og lærd. Han ble en fetert forskningsprofessor uten rutineplikter, rastløst ute etter nye oppdagelser, men var mislykket som forsker. «He should have spent the rest of his life practicing medicine» (2). Banting omkom i en flyulykke på vei til England.

Charles Best ble av mange, inklusive ham selv, oppfattet som forbigått ved nobelpristildelingen i 1923 (15). En som støttet dette synet var den svenske endokrinologen Rolf Luft (1914-2007) (16). Men Best klarte aldri, like så lite som Banting, å fremstille en pancreasekstrakt som var egnet til klinisk bruk.

I en lengre artikkel fra 1993 omtaler Bliss hva han kaller vedvarende forsøk fra Bests side på å omskrive historien om oppdagelsen av insulinet (17). Denne omskrivningen, som Best i en årrekke lyktes med, kunne til tider få preg av «a deliberate, unethical exercise in falsification which verges on scientific fraud». Men i Bliss' øyne blir likevel Best i historiens lys stående som en patetisk figur heller enn en svindler: Han må ha hatt et alvorlig egoproblem med en dyptgripende trang til anerkjennelse, sammen med psykologisk usikkerhet og dårlig dømmekraft.

Den som mest følte seg forbigått av nobelkomiteen var Paulescu (18). Og det er ikke tvil om at han, liksom Kleiner i New York, observerte den biologiske virkningen av insulin før Toronto-gruppen. Paulescus resultater ble for øvrig misoppfattet

i Toronto (2), kanskje pga. kanadiernes, overraskende nok, mangelfulle franskkunnskaper. Paulescus ettermæle er skjemmet av antisemittiske holdninger som var ganske utrerte. Han var også antidarwinist og doserte kreasjonisme for studentene. Men

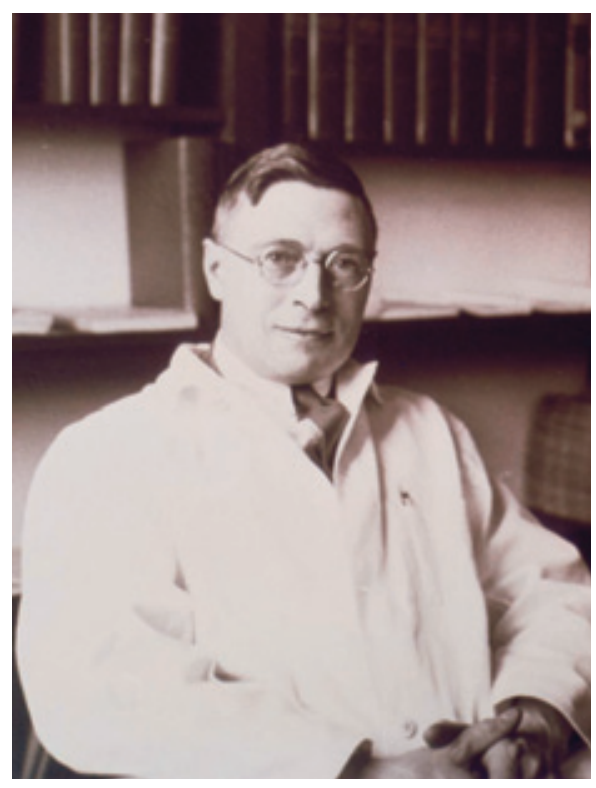

James B. Collip (1892-1965) fremstilte det første insulin til klinisk bruk. Thomas Fisher Rare Book Library, University of Toronto

vi har ingen grunn til å tro at slike politiske og kulturelle synspunkter innvirket på hans kandidatur til nobelprisen.

Det ligger utenfor denne artikkelens ramme å drøfte insulinbehandlingens medisinske og humanitære implikasjoner. Denne behandlingen har i sannhet en dramatisk virkning, noe som kan attesteres av alle som har sett diabetespasienter våkne opp fra ketoacidotisk koma. I dagliglivet, derimot, er det mye slit og mindre dramatikk. Insulintilførsel er en krevende substitusjonsbehandling som bare kan bli god når den

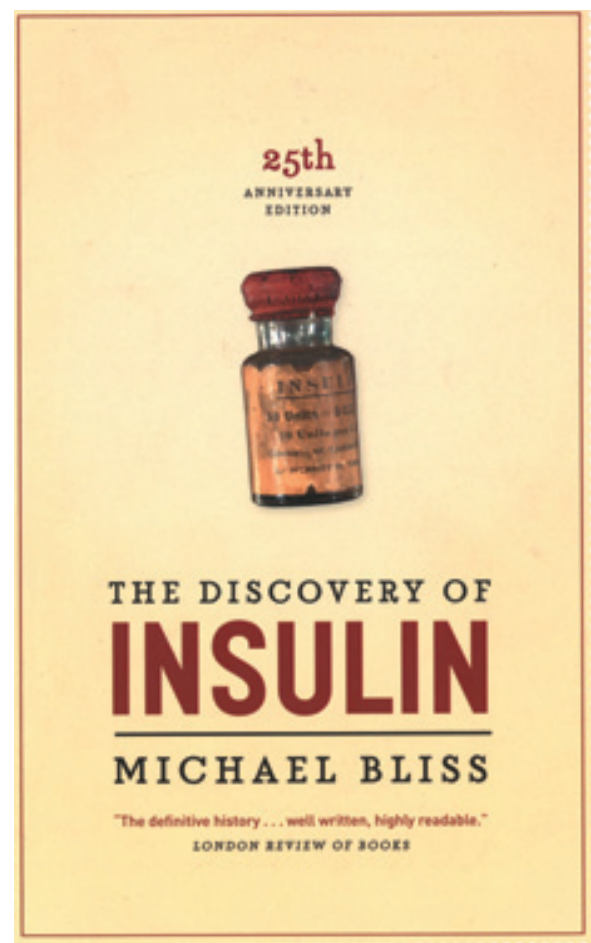

Faksimile fra Michael Bliss' bok om oppdagelsen av insulinet. Gjengitt med tillatelse (3) 
Torsidn!̣ IIDe janmar 1924

\section{Kjøp Nydalens Bomuldstøier}

\section{Vidunderstoffet insulin.}

\section{Det brukes nu i stor utstrækning i Norge. - Litt om de gunstige resultater paa Rikshospitalet.}

\section{En norsk fabrik vil nu fremstille stoffet.}

\begin{tabular}{|c|c|c|}
\hline 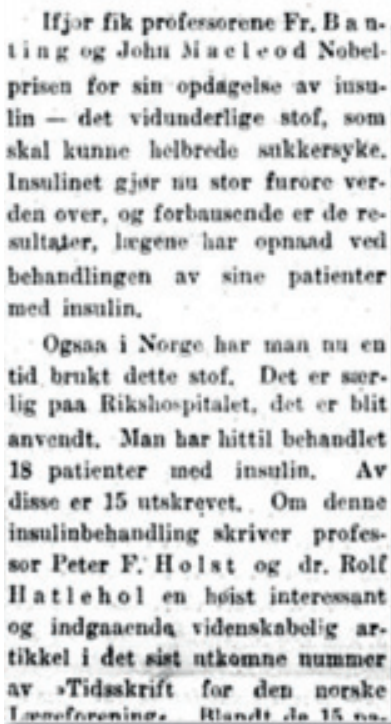 & 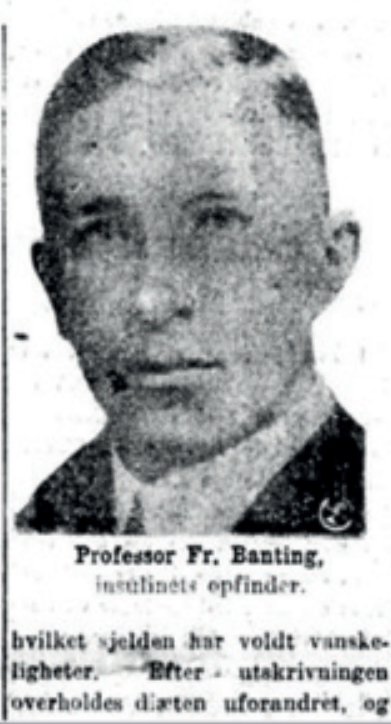 & 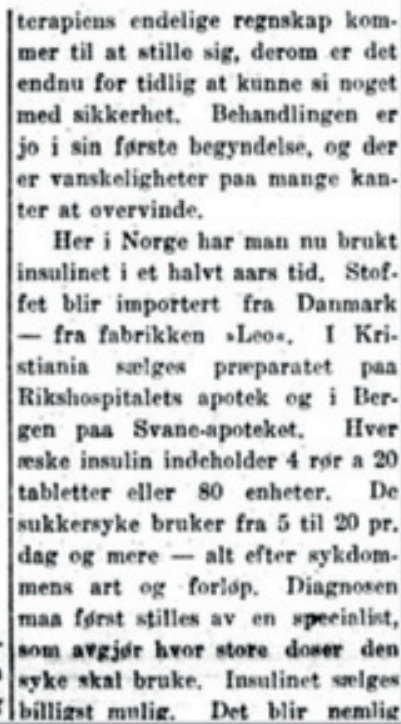 \\
\hline
\end{tabular}

Faksimile fra Aftenposten 10. januar 1924

er brukerstyrt. Fundamentalt sett er insulinbehandlingen den samme i dag som for 90 år siden, selv om det har skjedd innovasjoner og store forbedringer av de tekniske hjelpemidler.

Med insulinbehandlingen ble diabetes (senere diabetes type 1) stående som prototypen på en somatisk sykdom med rasjonell terapi. Dette ble legens domene par excellence. I kvakksalverloven fra 1936 ble sukkersyke nevnt særskilt i §4 (19). Denne loven ble opphevet i 2004. Hvor klokt dette var, kan diskuteres.

Introduksjonen av insulinbehandling ble ikke den endelige løsningen av diabetesproblemet. For insulinbrukerne ble det et liv med blodsukkermålinger, insulininjeksjoner og justering av pumper. Mange har fătt opp- leve frustrasjon og motgang i anstrengelsene for å unngå diabetiske senkomplikasjoner. Håpet, og forventningen, ligger i en gjenopprettelse av det som fundamentalt sett har gått tapt ved type 1-diabetes, nemlig de insulinproduserende betacellene i bukspyttkjertelen.

\section{Oddmund Søvik (f.1933)}

er professor emeritus, Institutt for klinisk medisin, Universitetet i Bergen. Frem til aldersgrensen (2003) var han overlege ved Barneklinikken, Haukeland universitetssykehus, med diabetes og arvelige metabolske sykdommer som særlige interesser. Ingen oppgitte interessekonflikter.
Litteratur

1. Porter R. The greatest benefit to mankind: a medical history of humanity from antiquity to the present. London: Harper Collins, 1997.

2. Bliss M. The discovery of insulin. Chicago: The University of Chicago Press, 1982.

3. Bliss M. The discovery of insulin. 25th anniversary edition. Chicago: The University of Chicago Press, 2007

4. Banting F. Diabetes and insulin. Nobel Lectures, Physiology or Medicine 1922-1941. Amsterdam: Elsevier, 1965. http://nobelprize.org/nobel_prizes/ medicine/laureates/1923/banting-lecture.html (25.3.2011).

5. Paulescu N. Action de l'extrait pancréatique. Comptes rendus des séances de la Société de Biologie 1921; 27: 555-9.

6. Kleiner I. The action of intravenous injections of pancreas emulsions in experimental diabetes.

J Biol Chem 1919: 40: 153-70.

7. Aarseth S. Insulin i 50 år. Tidsskr Nor Lægeforen 1972; 92: 39-40.

8. Banting FG, Best $\mathrm{CH}$, Collip JK et al. Pancreatic extracts in the treatment of diabetes mellitus. Can Med Assoc J 1922; 12: 141-6. www.ncbi.nlm.nih.gov/pmc/articles/PMC1524425 (25.3.2011).

9. Deckert T. Dr.med. H.C. Hagedorn og det danske insulin-eventyr. Herning: Poul Kristensens Forlag. 1998.

10. 80 år siden insulin kom til Norge. Tidsskriftets nettside 9.5. 2003. www.tidsskriftet.no/ ?nyhe id=1442 (25.3.2011)

11. Vidunderstoffet insulin. Det brukes nu i stor utstrækning i Norge. Aftenposten 10.1.1924: 1 www.aftenposten.no/arkivet (25.1.2011).

12. About insulin. International Diabetes Federation. www.idf org/about-insulin-0 (25.3.2011).

13. Diabetes historisk. Diabetesforbundet. www. diabetes.no/Diabetes+historisk.9UFRjS2H.ips (25.3.2011)

14. Broad WJ. Toying with the truth to win a Nobel. Anmeldelse av: Bliss M. The discovery of insulin. Science 1982; 217: 1120-2.

15. Rosenfeld L. Insulin: discovery and controversy. Clin Chem 2002; 48: 2270-88. www.clinchem.org/ cgi/content/full/48/12/2270 (25.3.2011).

16. Luft R. Vem upptäckte insulinet? Läkartidningen 1971; 68: 4997-5004.

17. Bliss M. Rewriting medical history: Charles Best and the Banting and Best myth. J Hist Med Allied Sci 1993; 48: 253-74. http://jhmas.oxfordjournals. org/content/48/3/253.long (25.3.2011).

18. Weber M. Book review. Anmeldelse av: Pavel I. The priority of N.C. Paulescu in the discovery of insulin. The Journal of Historical Review 1984 5: 101-4. www.vho.org/GB/Journals/JHR/5/1/ Weber101-105.html (25.3.2011).

19. Lov av 19. juni $1936 \mathrm{nr} 9 \mathrm{om}$ innskrenkning adgangen for den som ikke er norsk læge eller tannlæge, til å ta syke i kur. I: NOU 1998: 21. Alternativ medisin. www.regjeringen.no/nb/dep/hod/ dok/nouer/1998/nou-1998-21/20.html?id=141427 (25.3.2011)

Mottatt 31.1.2011, første revisjon innsendt 15.3. 2011, godkjent 8.4. 2011. Medisinsk redaktør Erlend Hem. 